\title{
Exploring Factors InfLuENCING OF Project Management Success in Public Building Projects in Nigeria
}

\author{
Akande, O.K., ${ }^{1,2 *}$ Olagunju, R.E., ${ }^{1}$ Aremu, S.C. ${ }^{3}$ and Ogundepo, E.A. ${ }^{4}$ \\ ${ }^{1}$ Department of Architecture, Federal University of Technology, Minna, Nigeria \\ ${ }^{2}$ Department of Civil Engineering, University of Leeds, Leeds, United Kingdom \\ ${ }^{3}$ Department of Architecture, Federal Polytechnic Bida, Nigeria. \\ ${ }^{4}$ Department of Statistics, Federal University of Technology, Minna, Nigeria. \\ * Corresponding author: fkakande225@googlemail.com
}

\begin{abstract}
In Nigerian, public building projects (PBPS) failure and abandonment constitutes one of the hindrances to the development of the nation's economic system. Therefore, the links between PBPS management success and the built environment professionals (BEPS) is becoming an important field of attention. This study evaluates the application of project planning techniques in PBPs in Nigeria and project planning challenges related to their successful delivery. Review of relevant literature combined with experts' input revealed twenty three factors; this form the basis for designing a questionnaire adopted to collect relevant data from BEPs. Findings identified poor strategic project planning aligned to project success, unrealistic expectation and overly bureaucratic hiccups from project initiators as the most critical factors influencing project management practices (PMP) affecting success in PBP delivery. The study suggests that unsuccessful project delivery is a reflection of inappropriately applied project planning techniques leading to serious project planning challenges.
\end{abstract}

Keywords: abandonment; failure; project planning; project management practices; public building projects.

\section{INTRODUCTION}

The importance of project management (PM) has been recognised by most built environment professionals (BEPs) and public agencies. This importance has also been acknowledged by several authors and scholars [1-5] within the literature indicating the ongoing discourse on PM, the difficulties associated with project delivery and the pervasiveness of project failure. Therefore, efficient PM takes on an important aspect of the success or failure in implementing any projects. Although numerous literatures exist on the subject of the PM, nevertheless, achieving effective PM remains a challenge as there continue to be problems resulting in several unsuccessful projects. According to [6] cited in [7] projects can be categorised into three resolution types - Resolution Type 1 (project success); implies that the project is completed on-time, on-budget, fulfilled all functions and features as specified. Resolution Type 2 (project challenged); this means that the project is completed and operational, but over-budget, over the time estimate, and offers fewer functions and features than originally specified. Resolution Type 3 (project impaired); implies that the project is cancelled at some point during the development cycle. 
Meanwhile, plethora of accounts has shown projects are unable to meet the expected requirements or deliver within time and on budget.

In 2008, [8] found that only $32 \%$ of all the projects surveyed succeeded (i.e. were delivered on time, on budget, with the required features and functions); $44 \%$ were challenged (late, over budget and /or with less than the required features and functions) and $24 \%$ of projects failed (cancelled prior to completion or delivered and never used). Thus, it has become increasingly clear that the problems remain in lack of appropriate project management practices (PMP) for successful project delivery. This underscores the importance of improving PMP in organisations. In Nigerian, PBP failure and abandonment constitute one of the impediments to the growth of the nation's economy. There are a plethora of reports about how this problem is perceived by various writers [9-11] to have underlying causes summarised as emanating from inadequate project planning, insufficient knowledge, unskillfulness, unsuitable application of planning techniques, limited understanding of critical factors for project planning and project success indicators. The incessant failure and eventual abandonment of several development projects in developing countries has become so pronounced such that Nigerian has continued to be one of the countries in such situation [10]. Hence, the significant effect that the situations have on the built environments' aesthetics cannot be overlooked. Meanwhile, the increase in new knowledge with resulting increase in complexity of PM has led to many organisations focusing on it. The purpose is to identify the critical factors responsible PBPs failure with a view to improving the delivery time and enhance its contribution to public PMP in Nigeria. The objectives that guided this study include;

- To investigate the application of project planning techniques in PBP management practices.

- To identify factors that significantly influence project success and responsible for project failure and abandonment and to ascertain their order (level) of importance.

\section{REVIEW OF LITERATURE AND THEORETICAL BACKGROUND}

Effective PMP in the public sector has been recognised to be a major determinant with the public sector establishments seeking corporate responsibility and how their growth policies can improve their efficiency and competitiveness. Also, there has been significant discussion in the project management literature with regards to factors influencing project delivery. For instance, surveys conducted in Jordan by [12] of fifty industrial public firms; explored the application of PM tools and techniques by the public sector and found that this was considerably lower. However, it establishes that when PM tools and techniques are employed by the public sector, they could efficiently result to tangible benefits in all aspects of planning, scheduling and monitoring. [13] conducted a review of literature to identify a range of success factors in the construction process and highlighted factors such as clearly defined project objectives, scope of the project, the project manager, project team, planning and control as key factors. Nevertheless, the study of [13] was determined primarily through theoretical approach without further empirical work. Therefore, adopting only literature review to draw their conclusion renders their findings inconclusive. In the UK, [14] observed the current PMP in the public sector using data collected from over two hundred project managers in some public institutions. Their result showed that 41 per cent of the project reported were found to be completely successful (using time, budget and specification) although not without certain shortcomings.

In Australia, [15] presented factors they considered critical to project success. In contrast to the approach adopted by [13] the authors employed survey method to obtain responses 
through the use of questionnaire from a hundred and fifty (150) respondents. Their findings indicated the key drivers responsible for successful projects as project's understanding, competent project team, communication, realistic schedule, cost estimates as well as adequate project control. In Italy, [16] recognised the effectiveness of the PMP in the public sector as an approach that could aid public sector to efficiently complete projects and also attain developmental objectives. According to the authors' studies on using PM methodology at the Italian Treasury Ministry, proper implementation of PM theories and approaches could aid continuous communication, project control system definition and the avoidance of project failure. In Pakistan, [17] investigated critical factors influencing the success of construction projects. The authors used a survey method by administering questionnaires to establish ten (10) factors they considered significant for successful construction projects. The factors include effective decision making, project manager and project contractor's experience, cash flow and client's timely decision. Meanwhile, in quite a number of developing countries, the application of up-to-date PM tools, methods and techniques is yet to be fully established in the public sector. This is partly responsible for several public sector projects resulting in failure and non-compliance to the requirements of the project's budget, specifications and deadlines. In Nigeria, some researchers [18] have argued that this is as a result of the social and political systems, cultural blocks and lack of financial support in the Nigerian public sector; which has created some hindrances to effective project planning and implementation.

In Nigeria, [19] undertook a quantitative approach to determining critical success factors influencing project performance. In their survey obtained from 188 questionnaires distributed within four regions of Nigeria, they identified five (5) factors such as objective management, management of design, technical factors, top management's support and risk management as key drivers to success. Meanwhile, in Libya, [20] assessed factors that influence success in construction projects and highlighted ten (10) factors they found to be critical to achieve successful delivery of construction projects. These were itemised as contractor's experience, project manager's leadership skills, labour productivity, quality relationship between team members, shortage of materials etc. A similar recent study conducted in Malaysia by [21] identified fifteen (15) key factors considered to be critical to construction project's success. The factors (i.e. financial capability of the client, control of contractor's work, consultant's competence, consultant's ability to solve problems, etc.) were found to be significant to delivery of construction projects to fruition. Additionally, other studies by [22] undertaken in Pakistan to assess the most critical success factors for mega construction projects reported five (5) factors as key drivers for construction project's success. The factors identified by the study include; planning efforts and scheduling, adequate funding, the ability of the project manager to decide, adequate planning and specification, timely decision making by the client.

Although, a number of studies have examined critical factors influencing project success across the globe and perspectives as noted above; one of the relatively under-researched areas is examining PMP and the delivery of specific projects in the building sector. Thus, the existing studies have a number of limitations such as the specificity of project coverage and parameters analysed. Likewise, few studies adopted a holistic approach to the methodology they use in assessing critical factors for project success or failure. Because the concepts of project failure, critical factors that influence project success and project type are central to this study; this study aims to address these current limitations by seeking to explore factors influencing PMP and the delivery of successful PBPs with specific focus on Nigeria. 


\section{MATERIALS AND METHODS}

\subsection{The Survey}

The data collection entailed using a questionnaire survey administered to greater number of BEPs in the construction industry and the academia with extensive experience in PBPs. The rationale for the selection of a survey approach, according to [23] is due to its benefits of recognising characteristics of a large group of individuals, as well as its economy of design and quick approach in data collection. The survey was conducted during the period February 2016 until July 2016 within the study area (i.e. Niger state, Nigeria) where 115 BEPs involved in PM participated.

\subsection{The Instrument}

The use of a questionnaire was identified as the most suitable instrument through which the respondents could be easily reached in the most economical [24] efficient and popular method to collect the required information. The questionnaire was administered to BEPs involved in public project planning and management and has carried out PBPs in their organizations. This improved the correctness of the data and its validity. A pilot study was carried out beforehand where 16 respondents were interviewed by using the planned, structured questionnaire to ensure the questionnaire was easily understood by the respondents.

\subsection{Sample selection}

The sample for the survey was drawn mainly from the two major regions of Niger state, Nigeria (i.e. Minna and Bida). In the study location, these two cities account for more than $90 \%$ of registered BEPs hence, the concentration of the data collection on the two cities. The respondents were selected from professionals located within the two cities. The professionals were selected using systematic sampling techniques from the available registered list of BEPs in the study area. According to [25] this minimizes bias. The questionnaires were sent through the help of research assistants. Phone calls were made to elicit their consent to participate in the study before the questionnaires were sent to them. Additionally, to prevent possible biases likely to originate from the sample already chosen for the qualitative interview in the questionnaire survey, the study deliberately excluded the 16 BEPs who have already been interviewed. Follow-up calls were made to the respondents of the survey questionnaire for prompt response.

\subsection{Data analysis method}

To accomplish the objectives of this study, descriptive statistics, use of relative importance index for ranking were adopted to analyse the responses obtained from the questionnaire. Descriptive analysis was employed to summarize the socio-demographic data while statistical analysis was carried out to examine the problems identified in this study.

\subsubsection{Validity and reliability}

Content and construct validity were used to determine the reliability and validity of the measurement items (scales) used in this study. According to [26] content validity refers to the extent to which a scale measures the concept it is intended to measure. 
Construct validity on the other hand indicates how well a test or experiment measures up to its claims [27]. The validity of the instruments was obtained using Cronbach's alpha determination and the scree plot of its factor analysis to ensure unidimensionality among the test items. To obtain the reliability of the instrument; the questionnaire was administered on 16 BEPs which were later excluded from the respondents for the study. Cronbach's alpha was computed for each scale using the SPSS 22. The scales had acceptable values and the respondents' responses internal consistency reliability coefficients value was 0.950 (Table 1). This is considered adequate when compared to an accepted value of 0.60 for new scales [28]. Hence, the items considered have content validity while their construct validity was tested using factor analys

\begin{tabular}{llccc}
\hline S/N & Items category & $\begin{array}{c}\text { No of } \\
\text { items }\end{array}$ & $\begin{array}{c}\text { Cronbach } \\
\text { alpha's value }\end{array}$ & $\begin{array}{c}\text { Reliability } \\
\text { status }\end{array}$ \\
\hline 1 & Level of knowledge of the project planning techniques and tools & 7 & 0.862 & Very good \\
2 & Level of utilization of the project planning techniques and tools & 7 & 0.883 & Very good \\
3 & What prevents the organization effectiveness in managing & 9 & 0.832 & Very good \\
& project and achieving & 3 & 0.863 & Very good \\
4 & Classification of projects in the past five years & 23 & 0.940 & Excellent \\
5 & Factors that have impacted project success rates in the past. & 49 & 0.950 & Excellent \\
\hline
\end{tabular}

Table 1. Questionnaire items and Cronbach's alpha score

\subsubsection{Relative Importance Index}

In this study, there was need to identify the prevalent factors to aid the decision and policy makers in their future decision required for direction in public PM approach and practices. Hence reliable and valid prevalence information is required to achieve such a feat. The use of relative importance index (RII) is considered as one of the means to determine such prevalence. In the questionnaire designed for this study, ranking of the level of importance was based on arithmetic mean value scores, using mainly Likert scales of 1-5. During the analysis, lower mean value indicates a lower level of importance of the factor [29] cited in [30].

\subsubsection{Factor Analysis}

Empirical information about critical factors for project management success was investigated by asking the respondents to rate from 1(low) to 5 (high) a set of items perceived to be factors which have impacted the respondents' project success rates. The items comprised of a set of 23 suggested potential factors identified from the literature influencing project success rate. This method of appraisal is adopted from a version of "project echo" procedure recommended by [31] for an initial phase of PM development. The 23 factors to measure the impact of the factors were subjected to principal components analysis (PCA) using SPSS version 22.

\section{RESULTS AND FINDINGS}

\subsection{Respondents' response rate}

Table 2 shows the number of questionnaires distributed and the respondents' response rates. Of the 150 questionnaires given out, only 115 were completed and received back. This represented $77 \%$ response rate. This response rate obtained is greater than others obtained in similar studies [32-34] having $25.4 \%, 55.25 \%$ and $55 \%$ respectively. 
Thus, the response rate obtained for this study is considered adequate for the analysis carried out as emphasised by [35] that the result of a survey with lower response rate between $30-40 \%$ is biased and of less valued.

\begin{tabular}{|c|c|c|c|}
\hline & Distribution (No) & Returned (No) & $\%$ of response rate \\
\hline Location & A & B & $(\mathrm{B} / \mathrm{A} * 100)$ \\
\hline Bida metropolis & 100 & 75 & $75 \%$ \\
\hline Minna metropolis & 50 & 40 & $80 \%$ \\
\hline Total & 150 & 115 & $77 \%$ \\
\hline
\end{tabular}

Table 2. Respondents' response rate

\subsection{Background Characteristics of Respondents}

Table 3 shows the background characteristics of the respondents in the study. As can be observed, the respondents with Masters' degree constitute the majority (36.3\%); followed by those with Bachelor degree (23.9\%) and HND holders (19.5\%). Very few $(8.8 \%)$ of the respondents had received doctorate degree with much fewer number having an Ordinary National Diploma (OND) education (7.1\%). This finding indicates that the majority of the respondents are educated. It is assumed that this could provide the foundation needed for understanding and using PM techniques and tools.

\begin{tabular}{|c|c|c|c|}
\hline Characteristics & Percentage & Characteristics & Percentage \\
\hline Level of Education & & Area of Specialization & \\
\hline GCE O/Level & .9 & Architecture & 36.0 \\
\hline OND & 7.1 & Building & 10.5 \\
\hline HND & 19.5 & Engineering & 21.1 \\
\hline Bachelor Degree & 23.9 & Estate Management & 8.8 \\
\hline Master's Degree & 36.3 & Quantity Surveying & 7.9 \\
\hline Doctorate Degree & 8.8 & Project Management & 6.1 \\
\hline Others & 3.5 & Others & 9.6 \\
\hline Professional Association & & Years of Experience & \\
\hline Association of Project Managers & 13.5 & $1-5 \mathrm{yrs}$ & 28.1 \\
\hline Nigeria Institute of Architects & 30.8 & $6-10 y r s$ & 34.2 \\
\hline Nigeria Institute of Quantity Surveys & 5.8 & $11-15 y r s$ & 18.4 \\
\hline Nigeria Institute of Management & 8.7 & $15-19 y r s$ & 12.3 \\
\hline Others & 41.3 & 20yrs and Above & 7.0 \\
\hline Average Number of Building Projects & & Cost of Building Projects & \\
\hline Handled Over the Last 5yrs & & Managed Over the Last $5 \mathrm{yrs}$ & \\
\hline $1-5 \mathrm{yrs}$ & 27.7 & 1 - 5 Million & 18.8 \\
\hline $6-10 y r s$ & 39.3 & $6-10$ Million & 17.9 \\
\hline $11-15 y r s$ & 17.9 & $11-15$ Million & 15.2 \\
\hline $15-19 y r s$ & 5.4 & 15-19 Million & 7.1 \\
\hline 20yrs and Above & 9.8 & 20Million and Above & 41.1 \\
\hline \multirow{2}{*}{ Course Taken in Project Management } & & Knowledge of Project & \\
\hline & & Planning Techniques & \\
\hline Yes & 74.0 & Yes & 82.6 \\
\hline No & 26.0 & No & 17.4 \\
\hline
\end{tabular}

Table 3. Summary of background profile of the respondents 
In Table 3, it can be seen that most of the respondents (36\%) were Architects; followed by Engineers (21.1\%); Builders (10.5\%); Estate Managers (8.8\%); Quantity Surveyors (7.9\%) and surprising only $6.1 \%$ were Project Managers. Among these respondents, $71.9 \%$ have more than five years work experience this translates to the fact that they are well established professionally. Further observation from Table 3 revealed that the majority of the respondents' professional affiliation is with the Nigeria Institute of Architects $(30.8 \%)$, followed by the Association of Project Managers (13.5\%); Nigeria Institute of Management (8.7\%) and Nigeria Institute of Quantity Surveyors (5.8\%).

According to Table 4, the three main building projects undertaken by the respondents are housing (37.5\%), education (23.08\%) and commercial (15.38\%). The largest $(39.42 \%)$ of these projects are carried out at the federal level, while those from private organization are made up $35.60 \%$; and $18.27 \%$ from the state level with the smallest percentage (6.73\%) from the local government level.

\begin{tabular}{|c|c|c|c|c|c|c|}
\hline \multirow{2}{*}{$\begin{array}{l}\text { Type of building } \\
\text { projects }\end{array}$} & \multicolumn{4}{|c|}{ Sources of project } & \multirow[b]{2}{*}{ Total } & \multirow[b]{2}{*}{ Percentage } \\
\hline & Fed. & State & Local & Private Org. & & \\
\hline Health Sector & 1 & 2 & 2 & 0 & 5 & $4.81 \%$ \\
\hline Housing & 14 & 4 & 1 & 20 & 39 & $37.50 \%$ \\
\hline Education & 17 & 4 & 1 & 2 & 24 & $23.08 \%$ \\
\hline Offices & 5 & 2 & 0 & 2 & 9 & $8.65 \%$ \\
\hline Commercial & 3 & 4 & 2 & 7 & 16 & $15.38 \%$ \\
\hline Industrial & 1 & 1 & 0 & 1 & 3 & $2.88 \%$ \\
\hline Others & 0 & 2 & 1 & 5 & 8 & $7.69 \%$ \\
\hline Total & $\begin{array}{c}41 \\
(39.42 \%)\end{array}$ & $\begin{array}{c}19 \\
(18.27 \%)\end{array}$ & $7(6.73 \%)$ & $\begin{array}{c}37 \\
(35.60 \%)\end{array}$ & $\begin{array}{c}104 \\
(100 \%)\end{array}$ & $100.00 \%$ \\
\hline
\end{tabular}

Table 4. Types and sources of building projects undertaken by respondents

\subsection{Respondents' knowledge of project planning techniques and tools}

The respondents' knowledge of project planning techniques and tools was determined by asking them to rate from 1 (Completely ignorant) to 5- (Very knowledgeable) their knowledge of the available techniques and tools used in project planning (Table 5). The respondents were presented with 7 options obtained from standard textbooks on PM and were asked to indicate their knowledge of the itemised techniques and tools.

\begin{tabular}{|c|c|c|c|c|c|c|c|c|c|c|}
\hline \multirow[b]{2}{*}{ Techniques/Tools } & \multicolumn{5}{|c|}{$\begin{array}{l}\text { Weighing Frequency } \\
\text { of Response }(\mathrm{X})\end{array}$} & \multirow[b]{2}{*}{$\sum F$} & \multirow[b]{2}{*}{$\sum F x$} & \multirow[b]{2}{*}{$\bar{X}$} & \multirow[b]{2}{*}{ RII } & \multirow[b]{2}{*}{ Rank } \\
\hline & 5 & 43 & 2 & 1 & & & & & & \\
\hline Critical path method (CPM) & 22 & 18 & 26 & 20 & 28 & 114 & 356 & 3.123 & 0.625 & $4^{\text {th }}$ \\
\hline $\begin{array}{l}\text { Program Evaluation Review } \\
\text { Technique (PERT) }\end{array}$ & 16 & 24 & 28 & 25 & 21 & 114 & 353 & 3.096 & 0.619 & $5^{\text {th }}$ \\
\hline Bar chart & 15 & 18 & 27 & 25 & 29 & 114 & 377 & 3.307 & 0.661 & $1^{\mathrm{st}}$ \\
\hline Line of balance & 20 & 21 & 23 & 23 & 27 & 114 & 358 & 3.140 & 0.628 & $3^{\text {rd }}$ \\
\hline Link bar chart & 21 & 21 & 28 & 24 & 20 & 114 & 343 & 3.009 & 0.602 & $7^{\text {th }}$ \\
\hline $\begin{array}{l}\text { Graphical Evaluation and } \\
\text { Review Technique (GERT) }\end{array}$ & 16 & 24 & 32 & 19 & 23 & 114 & 351 & 3.079 & 0.616 & $6^{\text {th }}$ \\
\hline $\begin{array}{l}\text { Project management software } \\
\text { (Microsoft project etc.) }\end{array}$ & 16 & 26 & 23 & 23 & 26 & 114 & 359 & 3.149 & 0.630 & $2^{\text {nd }}$ \\
\hline
\end{tabular}

Table 5. Respondents' knowledge of project planning techniques/tools 
The result of the analysis from Table 5 shows the top three of respondents knowledge areas of the project planning tools which are Bar chart (ranked $1^{\text {st }}$ ), PM software (ranked $2^{\text {nd }}$ ) and Line of balance (ranked $3^{\text {rd }}$ ). Critical path method (CPM), Program Evaluation Review Technique (PERT), Graphical Evaluation and Review Technique (GERT) and Link bar chart are some of the tools the respondents are completely ignorant of their application in project management. This shows that more important PM tools and techniques required for successful implementation of PBPs are less known to the respondents.

\subsection{Respondents' level of utilization of project planning techniques/tools}

Apart from the respondents' knowledge of project planning techniques and tools that was determined, in like manner, their level of utilization of the tools they are knowledgeable about was also determined by asking them to rate from 1 (Don't know this method) to 5 (Always use this method). It can be seen from the result in Table 6 that the respondents rated the use of the Bar chart (ranked $1^{\text {st }}$ ) as most important tools they adopt for their project planning and management. This is followed by the use of PM software (ranked $2^{\text {nd }}$ ) and PERT (ranked $3^{\text {rd }}$ ).

\begin{tabular}{|c|c|c|c|c|c|c|c|c|c|c|}
\hline \multirow[t]{2}{*}{ Techniques/Tools } & \multicolumn{5}{|c|}{$\begin{array}{l}\text { Weighing Frequency } \\
\text { of Response (X) }\end{array}$} & \multirow[b]{2}{*}{$\sum \mathrm{F}$} & \multirow[b]{2}{*}{$\sum F X$} & \multirow[b]{2}{*}{$\bar{x}$} & \multirow[b]{2}{*}{ RII } & \multirow[b]{2}{*}{ Rank } \\
\hline & 5 & 4 & 3 & 2 & & & & & & \\
\hline Critical path method (CPM) & 23 & 17 & 36 & 21 & 17 & 114 & 334 & 2.930 & 0.586 & $6^{\text {th }}$ \\
\hline $\begin{array}{l}\text { Program Evaluation Review } \\
\text { Technique (PERT) }\end{array}$ & 17 & 20 & 38 & 20 & 19 & 114 & 346 & 3.035 & 0.607 & $3^{\text {rd }}$ \\
\hline Bar chart & 15 & 20 & 33 & 29 & 17 & 114 & 355 & 3.114 & 0.623 & $1^{\mathrm{st}}$ \\
\hline Line of balance & 22 & 26 & 21 & 24 & 21 & 114 & 338 & 2.965 & 0.593 & $5^{\text {th }}$ \\
\hline Link bar chart & 25 & 19 & 24 & 25 & 21 & 114 & 340 & 2.982 & 0.596 & $4^{\text {th }}$ \\
\hline $\begin{array}{l}\text { Graphical Evaluation and } \\
\text { Review Technique (GERT) }\end{array}$ & 24 & 23 & 28 & 21 & 18 & 114 & 328 & 2.877 & 0.575 & $7^{\text {th }}$ \\
\hline $\begin{array}{l}\text { Project management software } \\
\text { (Microsoft project etc.) }\end{array}$ & 20 & 24 & 23 & 25 & 22 & 114 & 347 & 3.044 & 0.609 & $2^{\text {nd }}$ \\
\hline
\end{tabular}

Table 6. Level of utilization of project planning techniques/tools by respondents

\subsection{Factors responsible for PBP failure}

According to [36] the data collected needs to meet certain requirements prior to carrying out factor analysis. For instance, the sampling adequacy determined from the Kaiser-Meyer-Olkin (KMO) measure of sampling adequacy falling within the range of $0.5<\mathrm{KMO}<0.7$ is mediocre; $0.7<\mathrm{KMO}<0.8$ is good; $0.8<\mathrm{KMO}<0.9$ is great, $\mathrm{KMO}>0.9$ is superb. For this study, the KMO obtained is 0.879 (Table7); this is considered great as it exceeds the recommended value of 0.6 [37]. Similarly, the data collected for this study also passes Bartlett's Test of Sphericity (BTS) [38] which tests the adequacy of the correlations between the variables. The BTS attained statistical significance (P-value $<0.001$ ) and supports the factorability of the correlation matrix (Table7). Thus, the correlation matrix was analysed as a recommended default for factor extraction using the result obtained from the ratings of respondents and shown by correlation matrix in Table 8 .

\begin{tabular}{lll}
\hline \multicolumn{2}{l}{ Kaiser-Meyer-Olkin Measure of Sampling Adequacy. } & 0.879 \\
\hline & Approx. Chi-Square & $1,037.703$ \\
\multirow{2}{*}{ Bartlett's Test of Sphericity } & df & 253 \\
& P-value & $<0.001$ \\
\hline
\end{tabular}

Table 7. KMO and Bartlett's Test 
This result served as the basis for the identification of factors responsible for PM failure and abandonment in PBPs in Nigeria. Two approaches of factor analysis namely: principal components analysis (PCA) and factor analysis that could be used for the study is identified. According to [39] the PCA is preferred above factor analysis because of its simplicity although both approaches often yield similar results. As a result, the PCA was used for this study. However, prior to performing PCA, the suitability of data for factor analysis was assessed and inspection of the correlation matrix revealed the presence of coefficients of 0.3 and above.

\begin{tabular}{|c|c|c|c|c|c|c|c|c|c|c|c|c|c|c|c|c|c|c|c|c|c|c|c|}
\hline Correlation & $\mathrm{X} \mathbf{I}$ & $\mathrm{X} 2$ & $x_{3}$ & $\mathrm{X} 4$ & $\mathrm{X} 5$ & $\mathrm{X} 6$ & $\mathrm{X} 7$ & $\mathrm{XS}$ & $\mathrm{X} 9$ & $\mathrm{X} 10$ & X11 & $\mathrm{X} 12$ & $\mathrm{X} 13$ & $\mathrm{X} 14$ & $\mathrm{X} 15$ & $\mathrm{X16}$ & $\mathbf{X} 17$ & $\mathrm{X18}$ & X19 & X20 & $\mathrm{X} 21$ & $\mathrm{X} 22$ & $\mathrm{X} 23$ \\
\hline $\mathrm{X} 1$ & 1 & & & & & & & & & & & & & & & & & & & & & & \\
\hline $\mathrm{X} 2$ & .667 & 1 & & & & & & & & & & & & & & & & & & & & & \\
\hline $\mathrm{X} 3$ & .607 & .494 & 1 & & & & & & & & & & & & & & & & & & & & \\
\hline $\mathrm{X} 4$ & .798 & .428 & .428 & 1 & & & & & & & & & & & & & & & & & & & \\
\hline X5 & .596 & .491 & .455 & .442 & 1 & & & & & & & & & & & & & & & & & & \\
\hline X6 & .748 & .440 & .403 & .356 & .513 & 1 & & & & & & & & & & & & & & & & & \\
\hline X7 & .600 & .517 & .477 & .537 & 391 & .493 & 1 & & & & & & & & & & & & & & & & \\
\hline X8 & .540 & .469 & .432 & .423 & .300 & 651 & .464 & 1 & & & & & & & & & & & & & & & \\
\hline $\mathbf{X 9}$ & .626 & .490 & 341 & .461 & .565 & .621 & .418 & .514 & 1 & & & & & & & & & & & & & & \\
\hline $\mathbf{X} 10$ & .400 & .474 & 358 & .358 & 365 & 353 & 325 & .456 & 388 & 1 & & & & & & & & & & & & & \\
\hline X11 & .582 & .425 & .490 & .415 & .319 & 300 & .466 & .498 & .447 & .625 & 1 & & & & & & & & & & & & \\
\hline $\mathrm{X} 12$ & .486 & .683 & .492 & .430 & .374 & .427 & .447 & .476 & 356 & .372 & .499 & 1 & & & & & & & & & & & \\
\hline $\mathbf{X} 13$ & .671 & .647 & .549 & .403 & .397 & 333 & .453 & .457 & .448 & .430 & 574 & .578 & 1 & & & & & & & & & & \\
\hline X14 & .450 & .393 & 357 & .472 & .443 & 378 & .515 & .316 & 332 & 307 & 398 & .419 & .44 & 1 & & & & & & & & & \\
\hline X15 & .548 & 365 & .359 & .427 & .409 & 356 & .367 & .485 & 376 & .490 & 505 & .430 & 611 & .366 & 1 & & & & & & & & \\
\hline X16 & .513 & .440 & .451 & .372 & .468 & .444 & .467 & .400 & 324 & .482 & 580 & .564 & .593 & .340 & 591 & 1 & & & & & & & \\
\hline $\mathbf{X 1 7}$ & .644 & 516 & 359 & 300 & .494 & 501 & 375 & .445 & 341 & 313 & $A 23$ & .584 & 551 & 390 & 571 & .570 & 1 & & & & & & \\
\hline X18 & .484 & .516 & .489 & .422 & .453 & .444 & .486 & .364 & 340 & .358 & 305 & .482 & .533 & .561 & .382 & .403 & $.4 \pi 0$ & 1 & & & & & \\
\hline X19 & .584 & .413 & .423 & .424 & .515 & .476 & .357 & .499 & 380 & .546 & 337 & .506 & .486 & .488 & 467 & .380 & .524 & 529 & 1 & & & & \\
\hline $\mathrm{X} 20$ & .489 & .407 & 359 & .435 & .544 & .461 & 318 & .373 & 356 & .331 & 375 & .386 & 365 & .322 & .460 & .477 & .326 & 514 & .523 & 1 & & & \\
\hline $\mathrm{X} 21$ & .713 & .450 & 357 & .377 & .346 & .506 & .555 & .380 & 348 & 307 & .490 & .545 & .589 & 342 & .384 & .439 & .504 & .459 & .424 & .493 & 1 & & \\
\hline $\mathrm{X} 22$ & .549 & 316 & .495 & 510 & .460 & .477 & .410 & .359 & 324 & .654 & 439 & .407 & 432 & .369 & 530 & .457 & .411 & .449 & 502 & 550 & .563 & 1 & \\
\hline $\mathrm{X} 23$ & .452 & 337 & 338 & .372 & .490 & .439 & .450 & .539 & .425 & 394 & .435 & 315 & 309 & .355 & 367 & .355 & .542 & 325 & .406 & .457 & .373 & .561 & \\
\hline
\end{tabular}

Table 8. Correlation Matrix of Factors responsible for public building project failure

The PCA was used to determine the lowest of factors that can be used to best ascertain the number of primary factors. To know the number of factors that should be retained, Kaiser's criterion, scree test and parallel analysis were used. According to [40] Kaiser's criterion or the eigenvalue rule is among the most techniques used which simply keeps factors with an eigenvalue of 1.0 or more and other factors for additional analysis. Using this technique, factors with an eigenvalue of 1.0 or more are kept for additional analysis. The PCA identified 4 out of 23 components with eigenvalues above 1 . This shows $-42.728 \%,-7.867 \%, 7.655 \%$ and $4.868 \%$ of the variance and explains $42.728 \%, 7.867 \%, 7.655 \%$, and $4.868 \%$ of the variance respectively. Other method used in this study is the Catell's scree test. This entails plotting each of the eigenvalues of the factors, checking the plot to determine the point at which the shape of the curve changes direction and become horizontal. Based on [41] recommendations, any factor(s) beyond the elbow or break in the plot should be considered as they will give the most explanation of the variance in the data set. An assessment of the Scree plot (Figure 1) shows a distinct discontinuity after the third component. As a result of the Catell's scree test, 3 components were retained for further analysis. This established the results of Parallel Analysis, which indicated 3 components with eigenvalues above the corresponding criterion values for a randomly generated data matrix of the same size ( 23 variables x 115 respondents). 


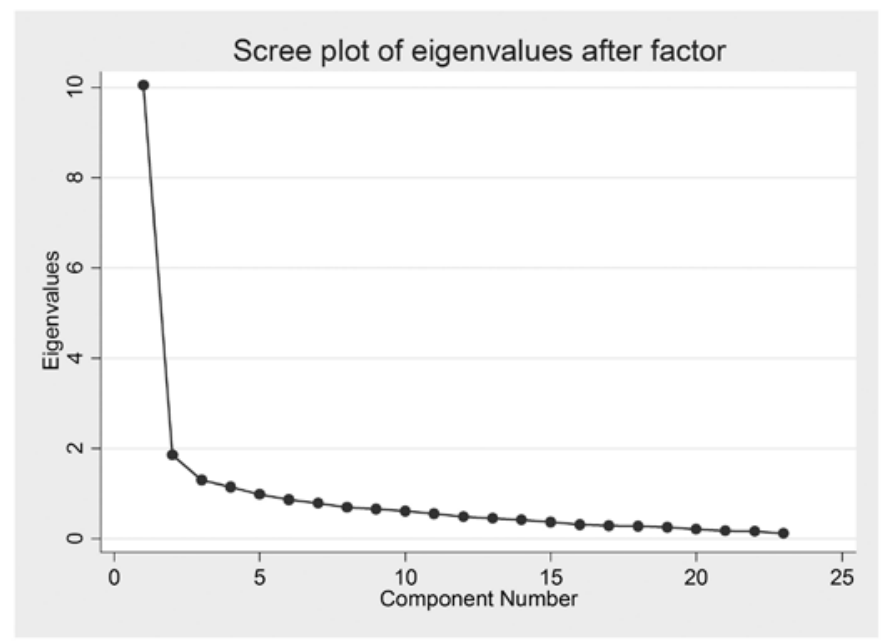

Figure 5. Catell's scree test

An additional technique used established through Horn's parallel analysis [42] is to relate the size of the eigenvalues with those previously gotten from a randomly generated data set of the same size. According to Table 9, only the eigenvalues above the equivalent values from the random data set are kept. Using this technique, the exact number of the components to be kept could be identified and shown to be the most correct. Meanwhile, according to [43-44], the Kaiser's criterion and Catell's screen test have the tendency to allow more than the required number of components.

\begin{tabular}{lcc}
\hline Eigenvalue & Random Eigenvalue & Standard Dev. \\
\hline 1 & 1.9206 & .0891 \\
2 & 1.7500 & .0634 \\
3 & 1.6274 & .0568 \\
4 & 1.5231 & .0502 \\
5 & 1.4303 & .0446 \\
\hline
\end{tabular}

Table 9. Monte Carlo PCA by Marley W. Watkins for Parallel Analysis

Since only three factors for principal component analysis with Kaiser's criterion are greater than that of parallel analysis as shown in Table 10 below, they were therefore retained.

\begin{tabular}{llll}
\hline $\begin{array}{l}\text { Component } \\
\text { number }\end{array}$ & $\begin{array}{l}\text { Actual eigenvalue } \\
\text { from PCA }\end{array}$ & $\begin{array}{l}\text { Criterion value from } \\
\text { parallel analysis }\end{array}$ & Decision \\
\hline 1 & 10.042 & 1.9206 & Accept \\
2 & 1.849 & 1.7500 & Accept \\
3 & 1.799 & 1.6274 & Accept \\
4 & 1.144 & 1.5231 & reject \\
\hline
\end{tabular}

Table 10. Comparison of actual eigenvalues of Kaiser's criterion to parallel analysis.

Findings show that the three-component solution explained a total of $58.3 \%$ of the variance, with Component 1 contributing 42.73\%, Component 2 contributing 7.87\% and Component 3 contributing $7.66 \%$ respectively (Table 11 ). 


\begin{tabular}{ccccccc}
\hline & \multicolumn{3}{c}{ Initial Eigenvalues } & \multicolumn{3}{c}{ Extraction Sums of Squared Loadings } \\
\% of & Cumulative & Total & of & Cumulative \\
& Total & Variance & $\%$ & & Variance & $\%$ \\
\hline 1 & 10.042 & 42.728 & 42.728 & 10.042 & 42.728 & 42.728 \\
2 & 1.849 & 7.867 & 50.596 & 1.849 & 7.867 & 50.596 \\
3 & 1.799 & 7.655 & 58.250 & 1.799 & 7.655 & 58.250 \\
\hline
\end{tabular}

Table 11. Relative importance of factors with three components retained

Principal Component Analysis with a varimax rotation was used and the Rotated Component Matrix (Table 12) gives a clearer picture of the factor loadings onto the three factors in the Table 11 above.

\begin{tabular}{|c|c|c|c|}
\hline \multirow[b]{2}{*}{ Variable (s) } & \multicolumn{3}{|c|}{ Component } \\
\hline & 1 & 2 & 3 \\
\hline Poor project planning & .739 & & \\
\hline Insufficient working capital & .716 & .401 & \\
\hline Inadequate monitoring and/or poorly carried out inspections & .698 & & \\
\hline Increase in contract sums & .641 & & \\
\hline Specification of costly imported materials & .554 & & .510 \\
\hline Contractor's incompetency leading to low performance & .552 & .313 & .487 \\
\hline Plans not used correctly & .499 & .455 & \\
\hline Haphazard award of contract without reference to funds availability & .474 & .352 & .405 \\
\hline Unrealistic expectation & & .763 & \\
\hline Major challenges in the project requirement & & 686 & .373 \\
\hline Haphazard completion of technically unsound project & .382 & 674 & \\
\hline Incorrect use of project methodology & .325 & 620 & \\
\hline Poor project finances & .402 & .567 & \\
\hline Escalation in total cost of project & .388 & .535 & \\
\hline Changing requirements and specifications & .398 & .488 & \\
\hline Inadequate resources & .456 & .462 & \\
\hline Initial cost and schedule not revised & .335 & .456 & .354 \\
\hline Challenges of delay in payment to contractors resulting from govt. Bureaucracy & & & .757 \\
\hline Frequent change in government & & & .749 \\
\hline Selection and award of contract based on lowest bidder & .442 & & .718 \\
\hline Increase in the scope of work & & .367 & .635 \\
\hline Poor or shoddy work by building professionals, consultants, etc. & .407 & & .566 \\
\hline Change in pre-contract consultants & & .444 & .564 \\
\hline
\end{tabular}

Table 12. Rotated Component Matrix with Varimax method

Factor 1 accounts for $42.7 \%$ of the total variance loads strongly in a positive direction on the factors such as poor project planning, insufficient working capital, inadequate monitoring and/ or poorly carried out inspections, increase in contract sums, specification of costly imported materials, contractor's incompetency leading to low performance, plans not used correctly and haphazard award of contract without reference to funds availability (Table 13). 
This factor may be called mal-alignment to project success. Factor 2 is responsible for $7.9 \%$ of the total variance and reveals high positive loadings on unrealistic expectations, major challenges in the project requirement, haphazard completion of the technically unsound project, incorrect use of project methodology, poor project finances, escalation in total cost of the project, changing requirements and specifications, inadequate resources, initial cost and schedule not revised (Table 13). This factor may be called unforeseen project challenges.

\begin{tabular}{lllc}
\hline Factor & Variables & Description & Factor Loadings \\
\hline \multirow{4}{*}{ X13 } & Poor project planning & 0.739 \\
X16 & Insufficient working capital & 0.716 \\
X12 & Inadequate monitoring and /or poorly carried out inspections & 0.698 \\
X19 & Increase in contract sums & 0.641 \\
X2 & Specification of costly imported materials & 0.554 \\
X17 & Contractor's incompetency leading to low performance & 0.552 \\
X15 & Plans not used correctly & 0.499 \\
X21 & Haphazard award of contract without reference to funds availability & 0.474 \\
\hline X11 & Unrealistic expectation & 0.763 \\
X7 & Major challenges in the project requirement & 0.686 \\
X18 & Haphazard completion of technically unsound project & 0.674 \\
X22 & Incorrect use of project methodology & 0.62 \\
X8 & Poor project finances & 0.567 \\
X5 & Escalation in total cost of project & 0.535 \\
X3 & Changing requirements and specifications & 0.488 \\
X20 & Inadequate resources & 0.462 \\
X4 & Initial cost and schedule not revised & 0.456 \\
\hline X6 & Challenges of delay in payment to contractors & 0.757 \\
X14 & resulting from government bureaucracy & 0.749 \\
X9 & Frequent change in government & 0.718 \\
X1 & Selection and award of contract based on lowest bidder & 0.635 \\
X10 & Increase in the scope of work & 0.566 \\
X23 & Poor or shoddy work by building professionals, consultants, etc. & 0.564 \\
\hline & Change in pre-contract consultants & \\
\hline & & \\
& & \\
& &
\end{tabular}

Table 13: Substantial factor loadings (Varimax)

In addition, Factor 3 accounts for $7.7 \%$ of the entire variance and reveal high positive loadings on challenges of delay in payment to contractors resulting from government bureaucracy, frequent change in government, selection and award of contract based on lowest bidder, an increase in the scope of work, poor or shoddy work by building professionals, consultants, etc., change in pre-contract consultants (Table 13). This factor may be called overly bureaucratic hiccups from project initiators. This analysis has established three critical factors based on twenty three factors that have impacted the project success rates in the past and have been classified accordingly i.e. namely mal-alignment to project success, unforeseen project challenges and overly bureaucratic hiccups from project initiator. 


\section{DISCUSSION OF FINDINGS}

The outcome of this study showed that greater numbers of BEPs are limited in knowledge with regards to appropriate use of planning techniques for PM. Although, according to the findings, the use bar chart is the most commonly use technique by the BEPs however, this is grossly inadequate to achieve successful project execution. This finding agrees with the view of several authors such as [45-47]. The authors argued that the use of bar chart is only appropriate for construction projects, planning when it is used along with CPM as a compliment. This indicates a poor approach towards project planning by the BEPs. Similarly, very few respondents make use of the application of computer software/package for project planning. This aligns with observations made by [48] on the low adoption of information and communication technologies (ICT) by BEPs for project planning and management. This demonstrates a need for acquisition in ICT skills and competency in project management planning. This agrees with the views of [49- 50] that project contractors are incompetent of delivering their contractual obligation. Likewise, the findings of [51] also affirm non-adoption of appropriate project management approach by BEPs. The results obtained from the factorial analysis show the critical factors influencing PBP success in Nigeria. According to the current study, malalignment to project success is the biggest challenge and the most critical factor responsible for PBP failure. Of high importance to successful project outcomes is the recognition from the inception that strategic project planning is important in avoiding project failure and increase project success. It is more demanding to determine the scope of any project without a considerable amount of upfront time, considerable thought, and coordination devoted to appropriate planning. These are necessary to gather the needed requirements, develop wide-ranging PM plans, and determine schedule activities. While it could be debated that the planning stage may seem to be more time consuming, however, it could result to preventing huge financial loss related with project failure and abandonment. It is noteworthy that in practice, effective project planning is mostly iterative in nature and it is worthwhile efforts to consider the attendant risks to poor planning. Therefore, effective project planning is important to limiting project failures and abandonment as it contributes to the possibility of project success and fundamental to successful project delivery. The third critical factor (i.e. the bureaucratic hiccups) is a reflection of the influence of the project initiators on the project outcome. In PM, flexibility and adequacy of funds should be a priority as it is one of the requirements for effective execution of project activities. Nonetheless, this may not be the case where there is no defined timely response from project initiators (i.e. the government) in the management of the project execution. With inadequate access to project funds, project executors (i.e. BEPs) are hindered from continuing the project. Therefore, crucial project components essential for project success become affected and eventually end up in project abandonment and failure.

\section{SUGGESTIONS AND RECOMMENDATIONS}

In views of the findings from this study, the authors recommends the following actions for effective PM practices and successful delivery of PBPs in Niger State and Nigeria in general; 1) the need for Nigerian BEPs to acquire more skills for effective management of PBPs; 2) introduce more ICT oriented approach to planning techniques and PM; 3 ) integrate continuous professional development (CPD) programmes in their professional training; 4) introduce PM courses in the training of BEPs and other construction related discipline in Nigerian institutions; 5) develop more risk management strategies to increase the likelihood of a successful project; 6) the state and federal government of Nigeria should be more committed to BEPs that apply up-to-date PM tools and techniques in managing PBPs and be more proactive in limiting and 
controlling the deep-rooted bureaucracy in all PBPs in order to curtail project failure and abandonment. Adherence to these recommendations could result to improved project planning; facilitate BEPs project management performance in meeting public project best practice and consequently to successful PBPs delivery.

\section{IMPLICATIONS OF THE STUDY FOR PRACTICE}

Due to the developing and growing nature of Nigeria's economy, huge capital intensive projects are currently being embarked on in every sector. Within the building sector, PBPs will entail suitable adoption of effective PM tools and techniques. The current study provides valuable insights for project initiators and BEPs to recognize critical factors that require attention for effective PM in the public sector. The appraisal of trend in public PM practices in this study would, thus, assist the government, BEPs and other decision maker to redirect their approach in the execution of PBPs to achieving successful project delivery. Similarly, the findings of this study would also assist Nigeria government to evaluate the ongoing PBPs, their PM practices and the possibilities of their success. The deficiencies of the BEPs in the application of project planning techniques and poor adoption of ICT could be appropriately addressed through improved training.

\section{CONCLUSION}

This paper has explored factors influencing PMP in the delivery of successful PBPs in Nigeria through an empirical approach. The study investigated the application of project planning techniques in PMP and operations in PBPs and found that limited knowledge and utilization of up-to-date project planning tools and techniques demonstrated by BEPs involved with PBPs are significant predictors of project failure. Although the current study may not have been without some limitations and deficiencies in its approach, such as the location and coverage area of study and deficiencies in the methodological approach, thus, further studies are required with larger samples and wider coverage area of study for in-depth understanding successful PBP delivery. Meanwhile, the key contribution of this paper lies in the identification of key factors, not previously identified by other authors that, if left unattended, strongly correlate with PBP failure and abandonment. This research demonstrates that a more refined approach is needed to realign project success from the onset of project planning to achieve successful project delivery. This will halt unforeseen project challenges exacerbated by overly bureaucratic hiccups from project initiators. Finally, there is a need for the BEPs and project initiators to adequately address the shortcomings observed through this study. This could be possible by the BEPs giving more attention to adequate training for continuous professional development in the art of PM. This is because unsuccessful project delivery is a reflection of inappropriate applied project planning techniques leading to serious project challenges. Meanwhile, the project initiators will need to address all unnecessary, time-consuming bureaucratic hiccups in order to improve the PBP success rate.

\section{ACKNOWLEDgmentS}

The authors will like to thank the reviewers for their time in critically reviewing and making suggestions to improve the quality of the paper. The authors would also like to acknowledge and declare no conflict of interest. 


\section{REFERENCES}

[1] ZwiKael, O., Bar-YosePh, B. Improving the capabilities of project team management using the Gestalt cycle of experience. Team Performance Management, 10 (2004) No7. 137-144.

[2] Winter, M., Sмith, C., Morris, P.W.G., Cicmil, S. Directions for future research in project management: the main findings of a UK government funded (EPSRC) research network. International Journal of Project Management. 24 (2006). No.8, 638-649.

[3] Thомas, J. Problematizing project management. In D. Hodgson \& S. Cicmil (Eds.), Making projects critical (2006). pp. 90-107. Hampshire: Palgrave.

[4] Geraldi, J., Maylor, H., Williams, T.. Now, let's make it really complex (complicated): A systematic review of the complexities of projects. International Journal of Operations and Production Management, 31 (2011) No 9, 966-990.

[5] McHugh, O., Hogan, M. Investigating the rationale for adopting an internationally-recognised project management methodology in Ireland. International Journal of Project Management (2011), p. 29

[6] Clancy, T. The Standish Group Report, 1995. http://www.projectsmart.co.uk/reports.html Chaos report.

[7] Atrarzadeh, I., Siew, H.O. Project Management practices. Success versus failure. International Symposium on Information Technology, 2008. ITSim 2008. Volume1: 1-8.

[8] Standish Group International. Chaos Summary 2009: the 10 laws of Chaos, International Standish Group., 2009.

Pp 1-4. http://ptslideshare.net/AccelerateManagement/chaos-summary-2009-the-standardish-group [Accessed:9th December 2012]

[9] Aкuta, C. V. Inconsistent Policies and High Rate of abandoned government projects. 2009.Nigeria News. http://www. ngex.com/news/public/article.php?ArticleID $=1343$

[10] Ayodele, E.O., Alabi, O. M. Abandonment of Construction Projects in Nigeria: Causes and Effects; Journal of Emerging Trends in Economics and Management Sciences (JETEMS), Vol. 2, 2011.Iss. 2, pp. 142-145.

[11] El-RufaI, N.A. The tragedy of abandoned projects. Nigeria Intel. 2012. http://www.nigeriaintel.com

[12] Aвbasi, Y. G., Al-Mharmah. 'Project management practice by the public sector in a developing country' International Journal of Project Management, 18 (2000). No3, pp105-109.

[13] Poon, J., Potts, K., Cooper, P. Identification of Success Factors in the Construction Process. A Conference Paper Delivered at COBRA (2001) Cutting Edge and ROOTS Conference.

[14] White, D., Fortune, J. 'Current practice in project management - an empirical study' International Journal of Project Management, 20 (2002) No.6, pp.1-11.

[15] Baccarini, D., Collins, A. Critical Success Factors for Projects, In Brown, A. (ed), Surfing the Waves: Management Challenges; Management Solutions. Proceedings of the 17th ANZAM Conference, (2003) .2-5 December, Fremantle, Western Australia.

[16] Arnaboldi M., Azzone G., Savoldelli A 'managing public sector project: the case of the Italian Treasury Ministry' International Journal of Project management, 22.(2004). No.3, pp213-223.

[17] Saqib, M., Farooqui, R.U., Lod, S.H. Assessment of Critical Success Factors for Construction Projects in Pakistan. First International Conference on Construction in Developing Countries (ICCIDC-1)"Advancing and Integrating Construction Education, Research and Practice, ., 2008 Karachi, Pakistan, 392-404.

[18] Idoro, G. I., Patunola-Ajayi, J. B. 'Evaluating the strategies for marketing project management system in the Nigerian construction industry', Nordic Journal of Surveying and Real Estate Research, 6 (2009). No.2, pp.25-36.

[19] Ogwueleka, A. The Critical Success Factors Influencing Project Performance in Nigeria. International Journal of Management Science and Engineering Management, 6. (2011) No.5, 343-349.

[20] Omran, A., Abdulbagei, M.A., And Gebril, A.O. An Evaluation of the Critical Success Factors for Construction Projects in Libya". International Journal of Economic Behaviour, 2, (2012)pp 17-25.

[21] Yong, Y.E., Mustaffa, N.E. Analysis of Factors Critical to Construction Project Success in Malaysia. Engineering, Construction and Architectural Management, 19. (2012) No. 5, 1-13.

[22] Ejaz, N., Hussain, J., Shabbir, F., Shamim, M.A., Naeem, U.A., Tahir, M.F. Assessment of Most Critical Success Factors for Mega Construction Projects in Pakistan. Life Science Journal, 10. (2013) No. 10, 255-261. 
[23] Luthans, F., Davis, T.R.V. 'An Idiographic Approach to Organizational Behavior research:The Use of Single Case Experimental Designs and Direct Measures', Academy of Management Review, JSTOR, 1982 http://www.jstor.org. ezproxy.liv.ac.uk/stable/pdfplus/257330.pdf

[24] Sarantakos, S. Social Research, Palgrave. New York. 1988.

25] LeEdy P.D. Practical research. New York: Macmillan Publishing. 1980

[26] Hasan, M. KerR, R.M.”The relationship between total quality management practices and organisational performance in service organisations". The TQM Magazine, Vol.15. (2003) Number 4. Pp 286-291.

[27] Shuttleworth, M. Construct Validity - Does the Concept Match the Specific Measurement? 2009. Explorable. com: https://explorable.com/construct-validity

[28] Nunnally, J.C. Psychometric Theory. 2nd Edition, McGraw-Hill, New York., 1978.

[29] Idrus, A., Sodangi, M. Framework for Evaluating Quality Performance of Contractors in Nigeria. International Journal of Civil and Environmental Engineering, 10. (2010) No. 01:34-39.

[30] Ibrahim, A. D. Investigating Into the Knowledge Requirements of Nigerian Quantity Surveyors to Meet Future Challenges. 25th Biennial Conference of The NIQS, 2011 pp. 7-18. Abuja: NIQS.

[31] Bavelas, A. "Project echo: Use of projective techniques to define reality in different cultures", Stanford University. 1968

[32] Emuze, F. A. Performance Improvement in South African Construction. South Africa: PhD Thesis NMMU. 2011

[33] Usman, N. A., Inuwa, I. I., Iro, A. I., Dantong, J. S. Training of Contractors Craftsmen for Productivity Improvement in the Nigerian Construction Industry. Journal of Engineering and Applied Sciences, 4, (2012) 1-12.

[34] Iro, A. I., Inuwa, I. I., Dantong, J. S. Investigation into Contractors Craftsmen Training in the Nigerian Construction Industry. International Journal of Engineering Research and Technology, 2 (2013) No1 pp1-6.

[35] Moser, C.A., Kalton, G. Survey methods in social investigation. UK: Heinemann Educational 1971.

[36] Field, A. Discovering Statistics, Using SPSS for Windows. Sage Publications, London., 2005.

[37] KaIser, H. A second generation Little Jiffy. Psychometrikal, 35, (1970) 401-15.

[38] Bartlett, M.S. A note on the multiplying factors for various chi square approximations. Journal of the Royal Statistical Society, 16 (1954) (Series B), 296-8.

[39] Stevens, J. Applied multivariate statistics for the social sciences $5^{\text {th }}$ edition. New York (N. Y.): Routledge. 2009

[40] Tabachnick, B.G., Fidell, L.S. Using Multivariate Statistics (5 ${ }^{\text {th }}$ Edn). Boston: Pearson Education. 2007

[41] Catell, R.B The Scree Test for Number Of Factors. Multivariate Behavioural Research, 1, , (1966) pp.245-76

[42] Horn, J. L. A rationale and test for the number of factors in factor analysis. Psychometrika, 30, (1965) 179-85

[43] Hubbard, R., Allen, S.J An empirical comparison of alternative methods for principal component extraction. Journal Of Business Research, 15, (1987). 173-90.

[44] Zwick, W.R., Velicer, W.F., Comparison of five rules for determining the number of components to retain. Psychological Bulleting, 99, (1986).432-42

[45] Abubakar, A. E., Grennwood, D., Osborne, A. A Study of Project Planning on Libyan Construction Projects. ARCOM Conference ., 2008 (pp. 789-798). Cardiff UK: Dainty, A. (Ed) Proceedings of the 24th Annual ARCOM Conference, 1-3 september, 2008.

[46] Krishnamurthy, K. G., Ravindra, S. V. Construction and Project Management: For Engineers, Planners and Builders. New Delhi: Satish Kumar J.2010.

[47] Chitkara, K. K., 2012. Construction Project Management: Planning, Scheduling \& Controlling. New Delhi: Tata McGraw-Hill.

[48] Мвамali, I., Окотіe, А. J. An Assessment of the Threats and Opportunities of Globalization on Building Practice in Nigeria. American International Journal of Contemporary Research, vol. 4 (2012) 143-150.

[49] Muazu, D. A., Bustani, S. A. A Comparative Analysis of Litigation Among Foreign and Indigenous Construction Firms in Nigeria. ATBU Journal of Environmental Technology, 3. (2004) No1: pp13-16.

[50] Aniekwu, A. N., Audu, H. O. The Effects of Management on Productivity: A Comparative Study of Indigenous and Foreign Firms in the Nigerian Construction Industry. Proceedings of West Africa Built Environment (WABER) Conference, 2010 (pp. 567-578). Accra-Ghana: WABER.

[51] Ekundayo, D., Jewell, C., Awodele, O. A. Executive Project Management Structure and the Challenges Facing its Adoption in the Nigerian Construction. International Journal of Architecture, Engineering and Construction. Vol.2. (2013) No.3 pp.158-169. 